\title{
Complex communication signals: the case of the Blue-black Grassquit Volatinia jacarina (Aves, Emberizidae) song. Part I - A structural analysis
}

\author{
HERNÁN FANDIÑO-MARIÑO ${ }^{1}$ and JACQUES M.E. VIELLIARD ${ }^{2 *}$ \\ ${ }^{1}$ Departamento de Biologia Animal e Vegetal, Universidade Estadual de Londrina \\ Cx. Postal 6101, 86051-970 Londrina, PR, Brasil \\ ${ }^{2}$ Laboratório de Bioacústica, Instituto de Biologia, Universidade Estadual de Campinas \\ Cx. Postal 6109, 13083-970 Campinas, SP, Brasil
}

Manuscript received on January 15, 2004; accepted for publication on February 5, 2004.

\begin{abstract}
The song of the Blue-black Grassquit Volatinia jacarina is different for every individual and the structural differences between individuals are quite complex. Samples of songs from different Brazilian localities, as well as from Venezuela and Mexico, were studied through a comparative analysis of their sonograms. From the structural point of view, the results show a song composed of a single note that is compacted in a "window" between 2 and $13 \mathrm{kHz}$ and rarely occupying more than half of a second. The note is essentially pure and is repeatedly uttered with a high level of fidelity. A global frequency modulation decreases from the beginning to the end of the song. The main song components are referred to as "Blocks" and are of three types: "Vibrations", (Buzzes or Vibratos), "Arabesques" (complex notes) and "Isolated Modulations", (simple syllables). Among other characteristics are double voices, which are quite diverse and probably function as codes for individual recognition. This song is considered a special case where a signature system has been developed to a high level of inter-individual variability.
\end{abstract}

Key words: Volatinia jacarina, Blue-black Grassquit, song structure, individual song.

\section{INTRODUCTION}

Individual variation in bird song has been observed and studied by different authors for several decades and the subject has revealed different kinds of differentiation among passerines (Nice 1943, Robinson 1949, Beer 1970, Falls 1982). In some cases, individual variation has reached high levels of differentiation and the concept of "signature" was proposed (Beecher 1982) for such songs where individual recognition seems to have been favored by natural selection.

\footnotetext{
*Member of Academia Brasileira de Ciências Correspondence to: Hernán Fandiño-Mariño E-mail: hernanf@uol.com.br
}

According to Falls (1982) neighbor-stranger discrimination was first demonstrated in the Ovenbird Seiurus aurocapillus, a species in which an individual male has a single, distinctive, stereotyped song. Comparable results have been obtained later for the White-throated Sparrow Zonotrichia albicollis (Falls 1969, Lemon and Harris 1974, Brooks and Falls 1975a), Indigo Bunting Passerina cyanea (Emlen 1971), Field Sparrow Spizella pusilla (Goldman 1973), and Common Yellowthroat Geothlypis trichas (Wunderle 1978). All these species show noticeable individual variation in their songs.

However the matter about how recognizable individual songs might be does not tell us much about 


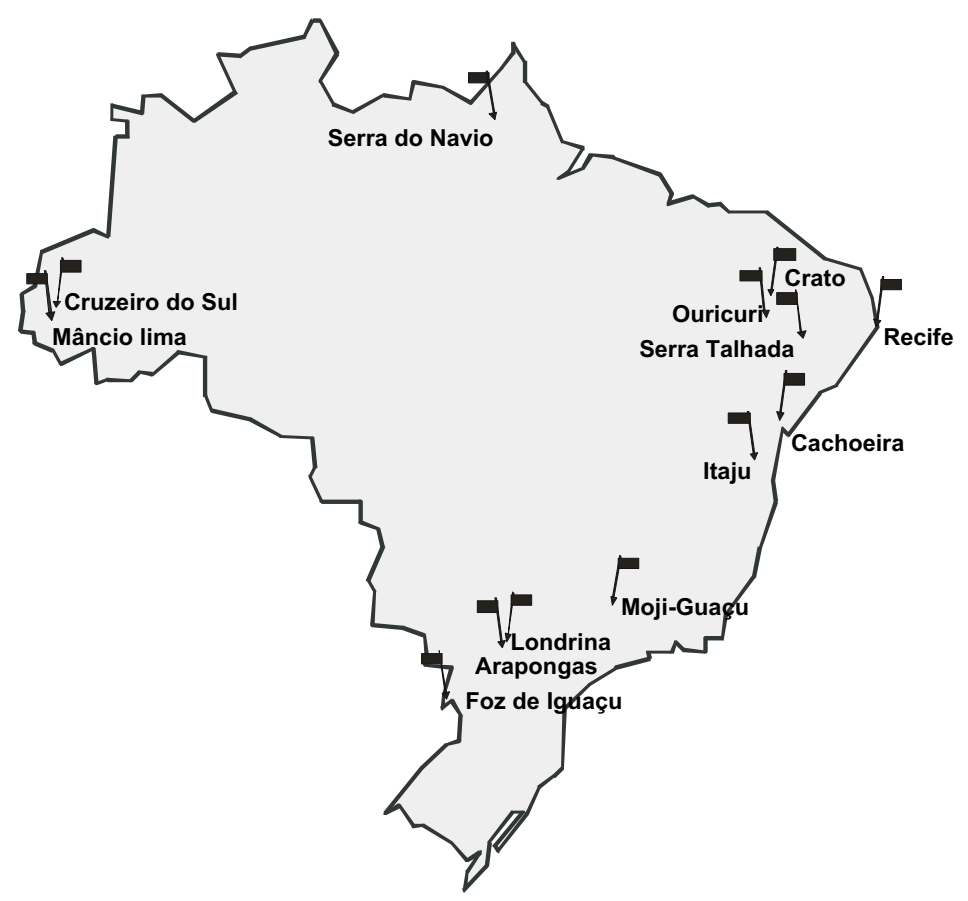

Fig. 1-Brazilian localities from which samples of Blue-black Grassquit Volatinia jacarina songs were obtained for sonographic analysis.

the degree of variation between them. The case of the Blue-black Grassquit Volatinia jacarina, that we are presenting here, deals with a model of variation that concerns the whole song, not just some distinctive parts of it. Such magnitude of structural difference between individuals was first observed by Vielliard (1987) who suggested the establishment of a new category of variations, named: "the individual song". This category would include two species: the Blue-black Grassquit Volatinia jacarina and the Uniform Finch Haplospiza unicolor. An individualistic song pattern had already been applied as a category (in the context of macrogeographic variations) to a single species: the White-throated Sparrow Zonotrichia albicollis by Mundinger (1982) although it was seen as enigmatic. Other complex communication patterns involving individual variation have been described in species such as the Rufus-bellied Thrush Turdus rufiventris in which versatility and intra-individual variation play a role (Silva 2001).
The first part of the study concerns a qualitative analysis of the song characteristics of the Blueblack Grassquit Volatinia jacarina. We search for a better definition of the individual variation of its songs, thus establishing a structural basis for further studies. The following sections will deal with the spatial distribution and geographic variation of the song, and are to be published later.

\section{MATERIALS AND METHODS}

Samples of songs from different places spread along the Brazilian territory (Fig. 1) and also from Venezuela and Mexico were studied through a comparative analysis of their sonograms. The samples were obtained through HF-M's own recordings made at the campus of the University of Londrina and a few other places in the State of Paraná; for the other localities we used the recordings available at the Arquivo Sonoro Neotropical (ASN) at the State University of Campinas (UNICAMP) and made mostly by JMEV. HF-M recordings were 


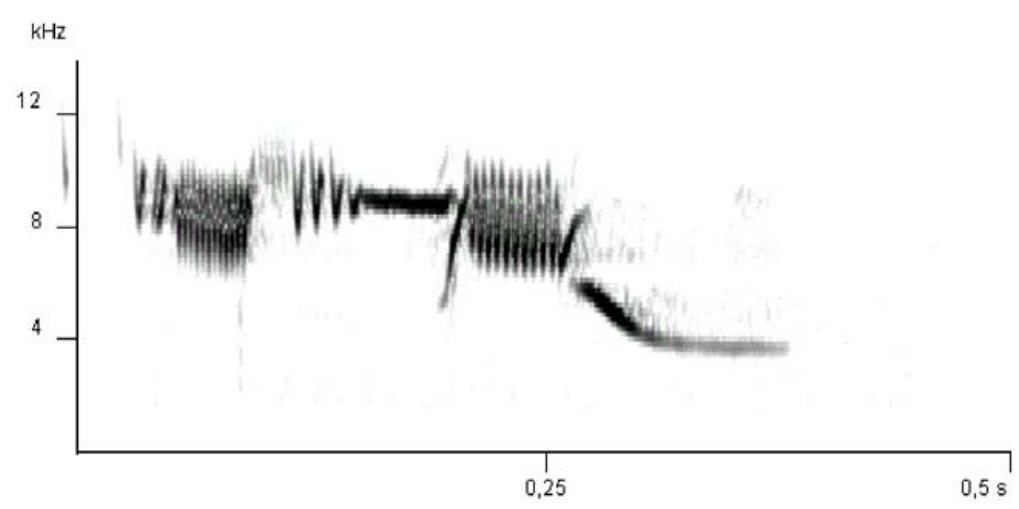

Fig. 2-Basic song structure of the Blue-black Grassquit Volatinia jacarina showing its single note compacted into a "window" between 2 and $13 \mathrm{kHz}$ and rarely occupying more than half of a second.

made with an UHER 4000 tape recorder and a directional microphone. The recordings at the ASN were made with different equipment, all of high fidelity. The analysis included 54 individuals. The spectrographic analysis was made through the Cool Edit Pro software.

\section{RESULTS}

From the structural point of view, the results show a song made of a single note that is compacted in a "window" between 2 and $13 \mathrm{kHz}$ and rarely occupying more than half of a second (Fig. 2). The note is essentially pure and is repeatedly uttered with a high level of stereotypy.

A global frequency modulation decreases from the beginning to the end of the song, the average initial frequency being $8,1 \mathrm{kHz}$ and the average final $3,5 \mathrm{kHz}$. The range of the frequency modulation is also different when comparing the beginning with the end of the song, the average initial range being $3,8 \mathrm{kHz}$ and the average final $1,1 \mathrm{kHz}$ (Fig. 3).

As it is also found in other species, the song is preceded by several identical notes, the Introductory Elements (Zann 1993) that are uttered in variable numbers. Such elements show a tendency to accelerate their rhythm until the start of the song itself. Finally there is sometimes the production of a mechanical noise, which is the result of wings clap- ping during the jump that eventually accompanies the song utterance. It starts before or comes together with the vocalizations and it appears on the sonogram in the form of pulses.

The main song components were called "Blocks" and are of three types: "Vibrations", "Arabesques" and "Isolated Modulations" (Fig. 4). There are still other Blocks that can be seen as "intermediary" between the three types mentioned. All the Blocks are linked to each other in the song and this is why the latter is considered a single note. This was also the reason why we introduced our own terminology: the description of elaborated elements of a single complex note appears to have no parallel in the ornithological literature.

\section{VIBRATIONS}

Vibrations are present in all the songs studied and thus they may be considered as a characteristic feature of the species song. Vibrations are frequency modulations of an approximately constant range that are repeated in a sequence over a variable period of time. Some notes of similar structure are found in other bird species and are frequently referred to as Buzzes or Vibratos. These modulations maintain a constant interval between them and so this repetition becomes a measurable frequency that we have called the Secondary Frequency (i.e. the frequency 


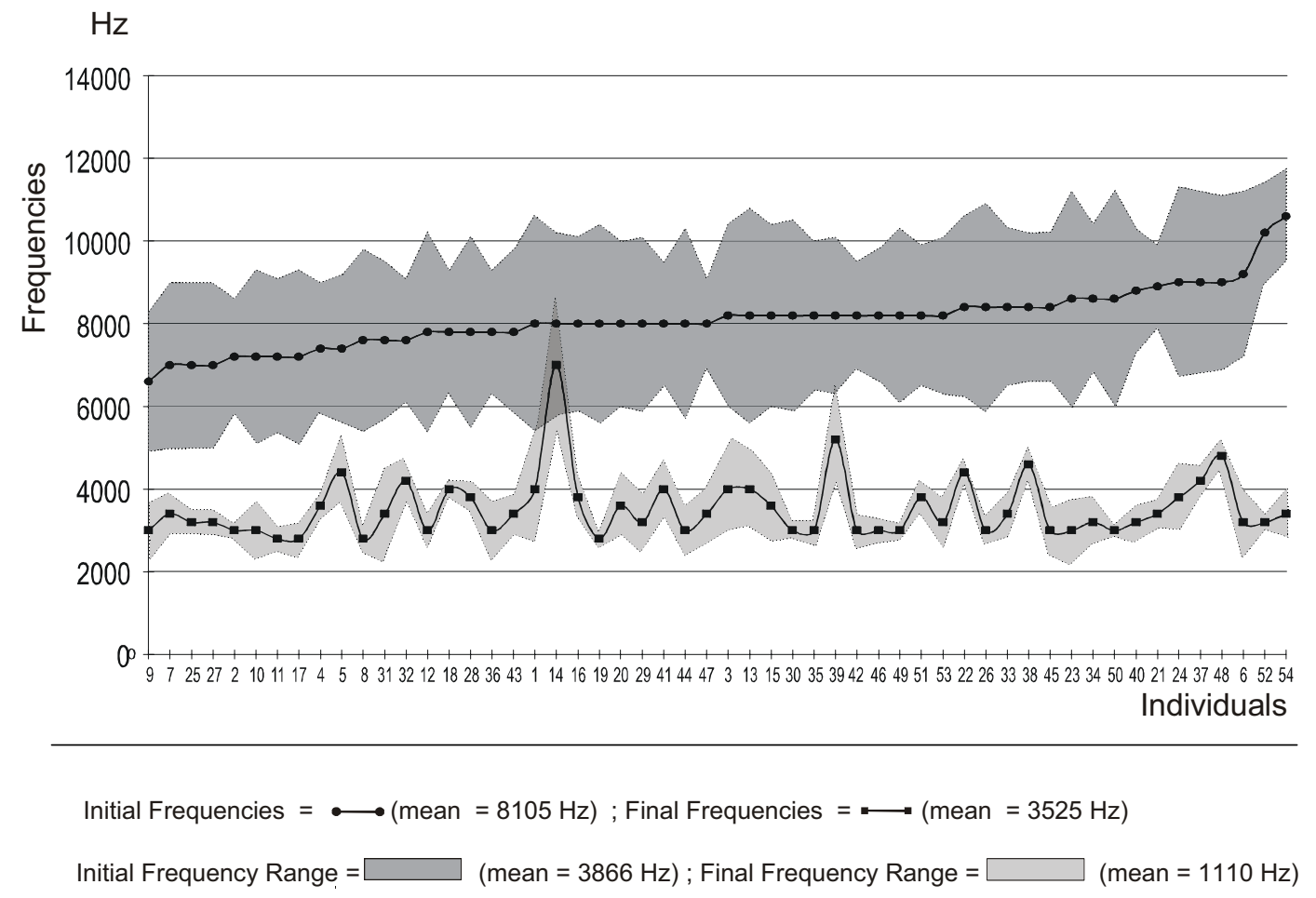

Fig. 3 - The initial frequencies of the song are always higher than the final frequencies. The frequency ranges are also larger when comparing the beginning with the end of the song.

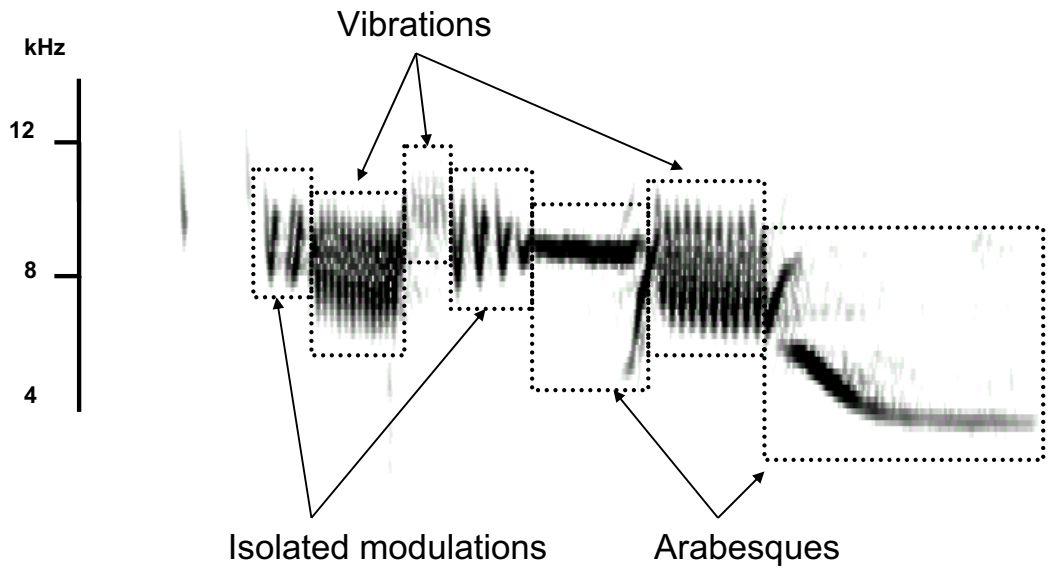

Fig. 4 - The three types of Blocks that represent the main song components: Vibrations, Arabesques and Isolated Modulations. 
of the Frequency of Modulation-FM) to distinguish it from the Primary Frequency of the Vibrations that corresponds to their mid frequency (Fig. 5). Vibrations show different types of modulations, some of which are exemplified on figure 6.

\section{ARABESQues}

This type of Blocks, in contrast with the Vibrations, shows band frequencies that are quite reduced in range $( \pm 1000 \mathrm{~Hz})$ while their Secondary Frequencies become relatively high (above $360 \mathrm{~Hz}$ ) making them indistinguishable for the discriminating capacity of the analysis program. On the sonogram they look like single compact structures that modulate twisting around in various ways somehow reminiscent of Arab letters.

\section{ISOLATED MODULATIONS}

These are frequency modulations that appear with a low number of repetitions. Their modulations simply go straight up and down, not twisting around, as some Arabesques do. Some notes of similar structure are found in other species and are frequently referred to as Simple Syllables. The Isolated Modulations frequently cover a large frequency spectrum that makes them quite noticeable, whilst they sometimes appear like elements of conjunction between other Blocks.

\section{INTERMEDIARY BLOCKS}

These are cases where a group of modulations can be considered either very compact Vibrations, either pretty loose Arabesques or any other intermediary structure, depending on the perspective used to look at the subject. In fact if Arabesques themselves have been conceived as compacted modulations, that means a process involving intermediary steps (Fig. 7).

\section{Double Voices}

Double voices are present in all the three kinds of Blocks. They make especially interesting effects on the Vibrations where the frequency spectrum becomes expanded to a wide range. One of such ef- fects was named Zipper Effect, simply because of the kind of image obtained sonographically. Zipper Effects include sometimes complex superpositions of the two voices at various degrees (Fig. 8).

\section{REPETITIONS}

Repetitions of different elements of the song are a common feature. Vibrations and Isolated Modulations are themselves repetitions. Repetitions can also be observed on Arabesques and the entire emission of a Block can be repeated as well. Sometimes long sections of a song become duplicated (Fig. 9).

\section{FIDELITY}

It is observed a high level of stereotypy in the renditions of the songs, which are uttered repeatedly by every individual for relatively long periods. Such fidelity must be estimated through specific programs specially designed for this purpose. Nevertheless a simple evaluation of the fidelity can be obtained by simply counting the number of modulations in the Vibrations as well as comparing their duration and frequencies.

\section{DISCUSSION}

Considering the features that can be involved in species-specific recognition, four of them deserve to be pointed out as candidates. In the first place, the limits of a window between 2 and $13 \mathrm{kHz}$ and 0.5 seconds. This type of characterization has also been mentioned for other species like Zonotrichia albicollis (Brooks and Falls 1975b) and Spizella pusilla (Nelson 1989). Secondly, the absence of silences (intervals) between the elements (Blocks) makes this song peculiar: a structurally complex song of a single note. In the third place, the global frequency modulation always decreasing from the beginning to the end together with the respective differences in band ranges are clearly a distinct and probable recognition feature. Syntactic organization has also been found to be of importance in the recognition affair for Parus atricapillus (Ratcliffe and Weisman 1986) and also for Melospiza melodia (Marler and Peters 1988). In the fourth and last place, we shall 

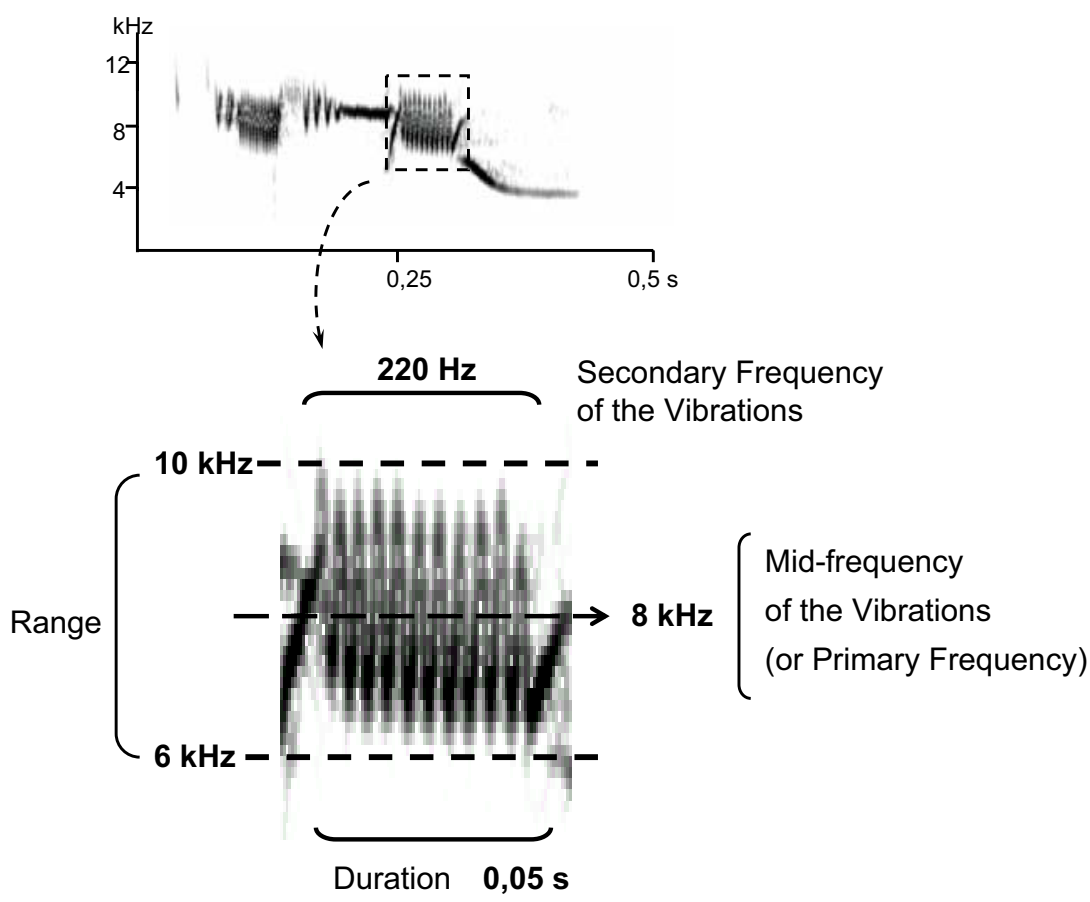

Fig. 5 - Example of Vibrations, with its structural parameters.

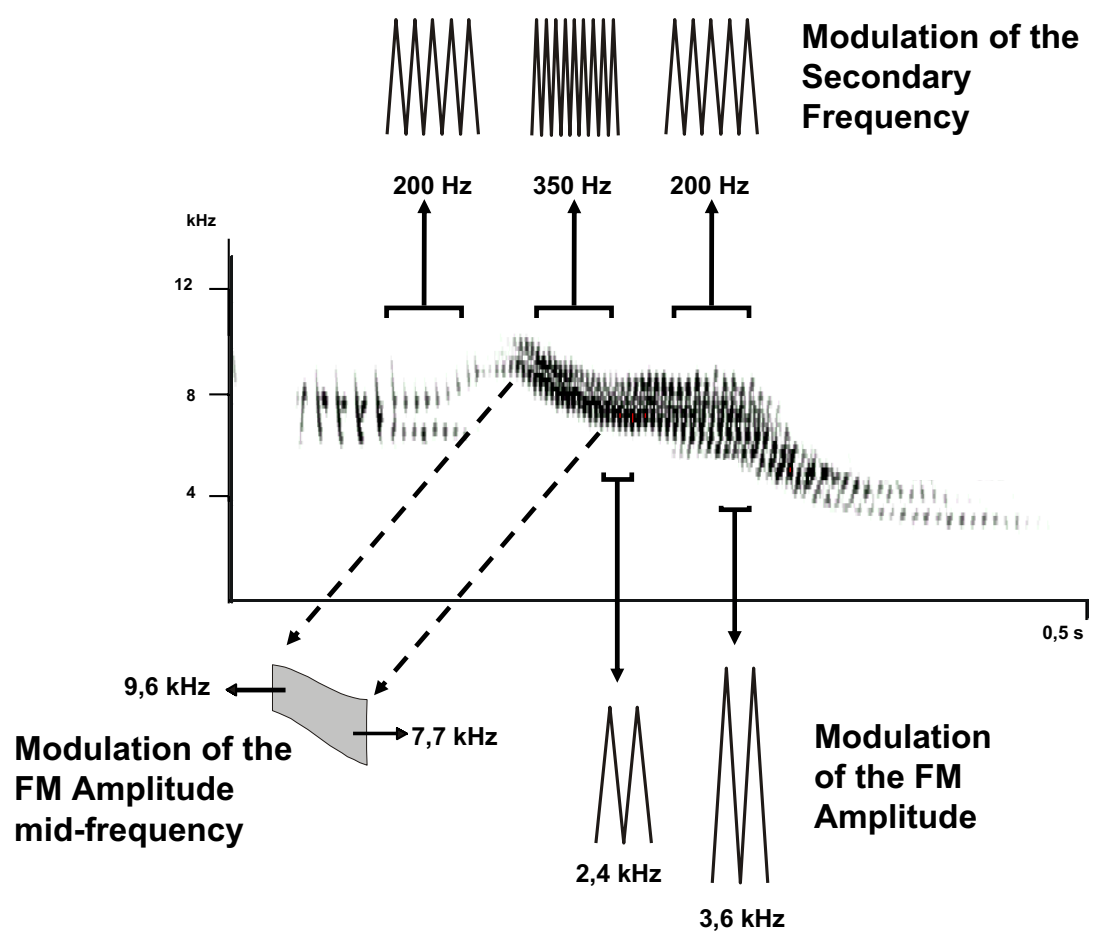

Fig. 6 - Example of modulations of the Vibrations, with its structural parameters. 

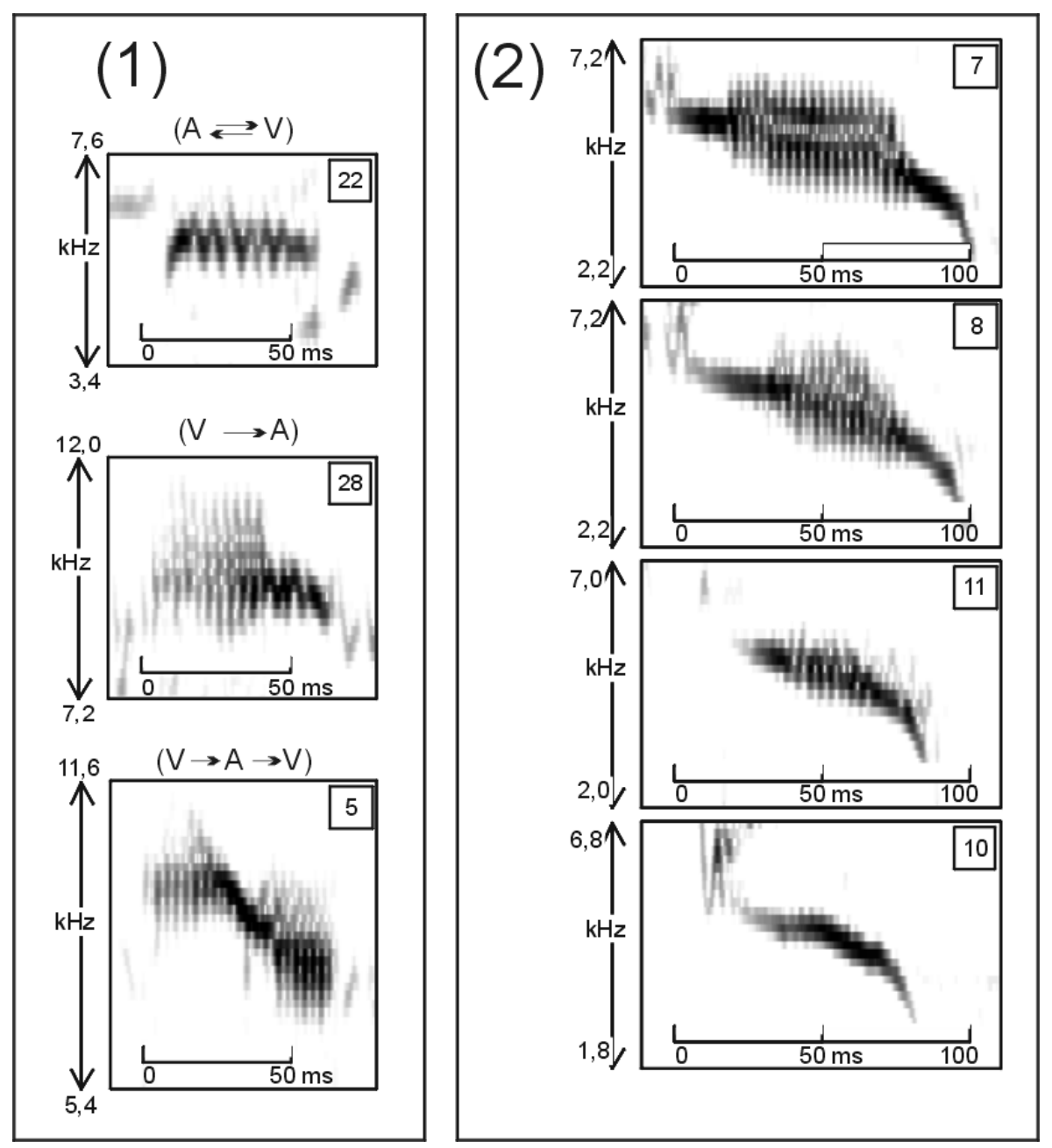

Fig. 7 - Intermediary structures: 1) temporary transformations between Vibrations and Arabesques; 2) sequence (starting up and going down) of progressive levels of condensation from Vibrations to Arabesques. A = Arabesque, $\mathrm{V}=$ Vibrations. The number in a square in the upper right corner of each sonogram refers to the individual singer.

consider the presence of Vibrations as another probable species-specific recognition feature. Thorpe and Lade (1961) went even further and suggested that such elements could well be considered a generic feature in the family Emberizidae.

Concerning the question of the individual recognition, a hypothesis named "signature system" suggests that natural selection makes the signals themselves more individually distinctive by increasing inter-individual variation and/or decreas- ing intra-individual variation in signal parameters (Beecher 1982, 1988, Loesche et al. 1991). This seems to be precisely the case of the Blue-black Grassquit where a special signature system has been developed to a high level in both inter- and intraindividual variation ways. The high level of differentiation includes special refinements such as the Secondary Frequencies of the Vibrations and several modulation forms as well as the complex combinations of the double voices, the zipper effects with 


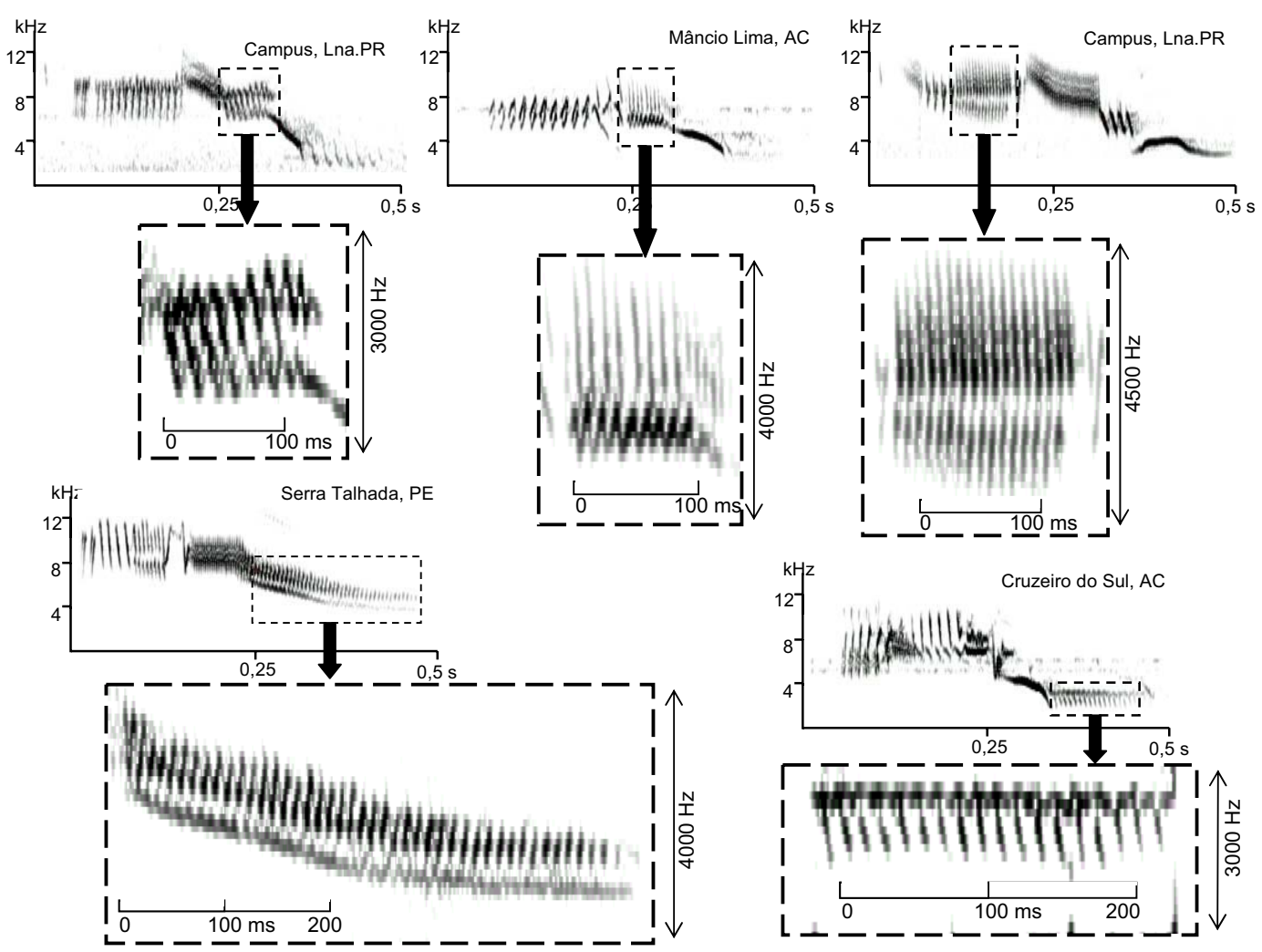

Fig. 8 - Examples of Double Voices on Vibrations: the "'Zipper Effect"' as shown in the enlarged inserts.

their remarkable synchronies.

Lambrechts and Dhondt (1995) discuss the subject of special signatures and perceptual adaptations and suggest that they may have evolved to facilitate individual vocal recognition. According to them, neighbor-stranger discrimination does exist in species having a single song and species having single-song repertoires are sensitive to relatively subtle differences in their songs. Song Sparrows (Stoddard et al. 1988) perceive small variations in the microstructure of song that could be used in individual recognition. Although we have not made any perceptual or recognition tests with the Blue-black Grassquit, we can expect significant adaptations at this level. It is difficult to imagine the development of such refined differentiations without the corresponding intra-specific communication functions.

Finally we find our data quite in agreement with Thorpe and Lade's (1961) comments when they state that: " ... the songs of the Emberizidae in general tend to be short, stereotyped, repetitive and simple.' The Blue-black Grassquit fits such a description pretty well with only one exception: its song is certainly not simple. It is understood however that, at first look, the song does not show its complexity, which becomes evident only after a meticulous sonographic analysis.

\section{RESUMO}

O canto do Tiziu Volatinia jacarina é único para cada indivíduo e as diferenças estruturais entre um e outro indivíduo são muito complexas. Cantos gravados em diversos lugares do Brasil e alguns da Venezuela e do México foram estudados através de uma análise comparativa dos seus sonogramas. Do ponto de vista estrutural, os resultados mostram que o canto é constituído por uma nota única que se encontra compactada numa "janela" entre 2 e 13 $\mathrm{kHz}$ e raramente ultrapassa meio segundo de duração. A 

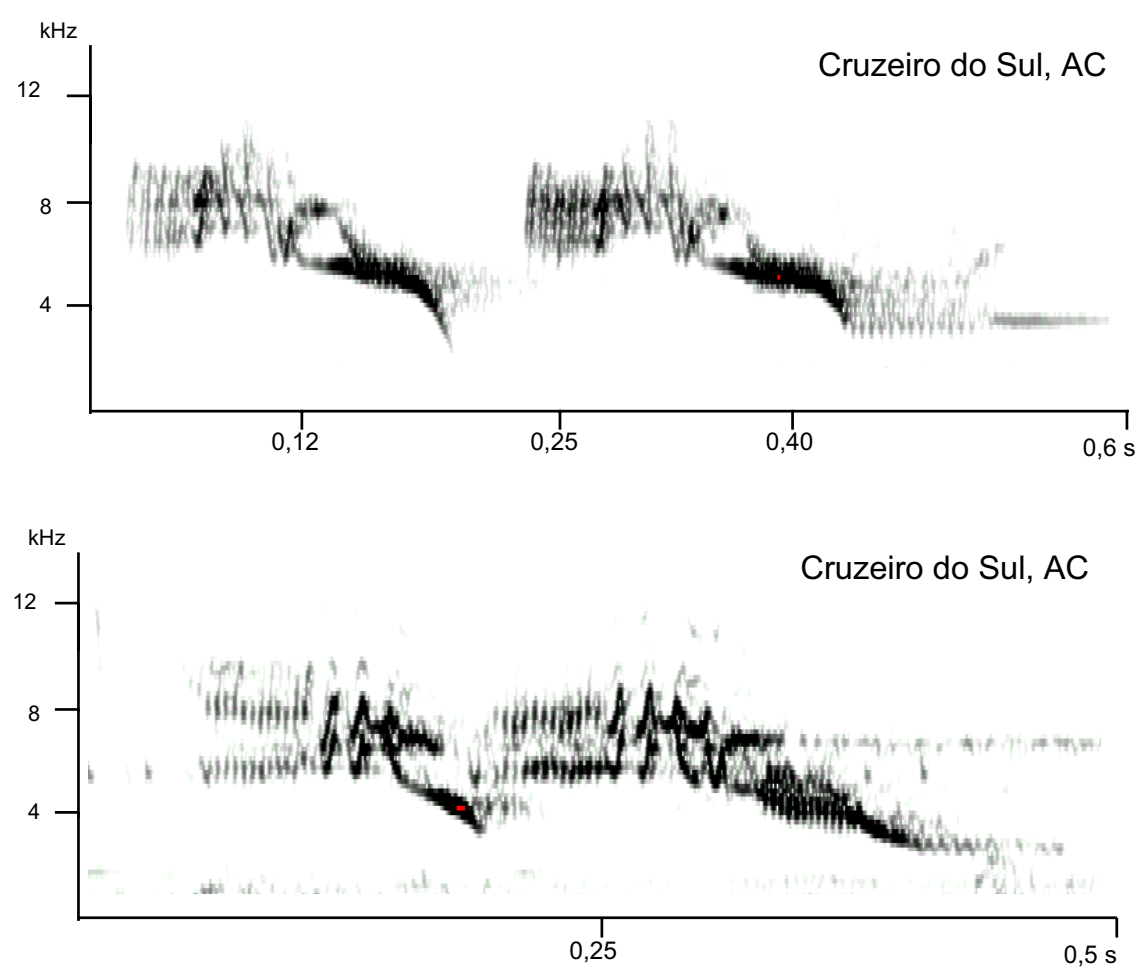

Fig. 9-Repetitions: two cases of individual singers showing long sections of their song duplicated.

nota, essencialmente pura, é repetida com alto grau de fidelidade entre uma emissão e outra. Constata-se uma modulação de frequiência global descendente do início ao fim do canto. Os principais componentes do canto do Tiziu foram denominados "Blocos", e são basicamente de três tipos: as "Vibrações", (Buzzes ou Vibratos), os “Arabescos", (notas complexas) e as "Modulações Isoladas" (sílabas simples). Entre outras características estão as "duplas vozes", que mostram ampla diversificação e têm por função servir de códigos para o reconhecimento individual. Consideramos o canto do Tiziu como um caso especial em que um "sistema de assinatura" foi desenvolvido a um elevado nível de variabilidade interindividual.

Palavras-chave: Volatinia jacarina, Tiziu, estrutura do canto, canto individual.

\section{REFERENCES}

BEECHER MD. 1982. Signature systems and kin recognition. Amer Zool 22: 477-490.
BeEcher MD. 1988. Kin recognition in birds. Behav Genet 18: 465-482.

BEER CG. 1970. Individual recognition of voice in the social behavior of birds. In: LEHRMAN DS, HINDE RA AND SHAw E. (Eds), Advances in the study of behavior, v. 3. New York: Academic Press, p. 27-74.

BroOKs RJ AND FALls JB. 1975a. Individual recognition by song in White-throated Sparrows. I - Discrimination of songs of neighbors. Can J Zool 53: 879-888.

BRooks RJ AND FALls JB. 1975b. Individual recognition by song in White-throated Sparrows. III - Song features used in individual recognition. Can J Zool 53: 1749-1761.

EMLEN ST. 1971. The role of song in individual recognition in the Indigo Bunting. Z Tierpsychol 28: 241-246.

FALLS JB. 1969. Functions of territorial song in the White-throated Sparrow. In: HINDE RA. (Ed), Bird vocalizations. London: Cambridge Univ. Press, p. 207-232.

FALLS JB. 1982. Individual recognition by sounds in birds. In: Kroodsma DE and Miller EH. (Eds), 
Acoustic communication in birds, v. 2. New York: Academic Press, p. 237-278.

Goldman P. 1973. Song recognition by Field Sparrows. Auk 90: 106-113.

LAMBrechts MM AND DhONDT AA. 1995. Individual voice discrimination in birds. Curr Ornithol 12: 115-139.

LEMON RE AND HARRIS M. 1974. The question of dialects in the songs of White-throated Sparrows. Can J Zool 52: 83-98.

Loesche P, Stoddard PK, Higgins BJ ANd Beecher MD. 1991. Signature versus perceptual adaptations for individual vocal recognition in swallows. Behaviour 118: 15-25.

Marler P ANd Peters S. 1988. The role of song phonology and syntax in vocal learning preferences in the Song Sparrow, Melospiza melodia. Ethology 77: 125-149.

Mundinger PC. 1982. Microgeographic and macrogeographic variation in acquired vocalizations in birds. In: Kroodsma DE and Miller EH. (Eds), Acoustic communication in birds, v. 2. New York: Academic Press, p. 147-208.

NELSON DA. 1989. Song frequency as a cue for recognition of species and individuals in the Field Sparrow (Spizella pusilla). J Comp Psychol 103: 171-176.

NiCE MM. 1943. Studies in the life history of the Song Sparrow. II. The behavior of the Song Sparrow and other passerines. Trans Linn Soc NY 6.
Ratcliffe L and Weisman RG. 1986. Song sequence discrimination in the Black-capped Chickadee (Parus atricapillus). J Comp Psychol 100: 361-367.

Robinson A. 1949. The biological function of bird song in Australia. Emu 49: 291-315.

SiLva ML. 2001. Estrutura e organização de sinais de comunicação complexos: o caso do Sabiá-laranjeira Turdus rufiventris (Aves, Passeriformes, Turdinae). Unpubl. thesis. São Paulo: Instituto de Psicologia, Universidade de São Paulo.

Stoddard PK, Beecher MD AND Willis MS. 1988. Response of territorial male Song Sparrows to song types and variations. Behav Ecol Sociobiol 22: $125-130$.

Thorpe WH AND LADE BI. 1961. The songs of some families of the Passeriformes. II. The songs of the buntings (Emberizidae). Ibis 103: 246-259.

VIELLIARD JME. 1987. Uso da bioacústica na observação de aves. In: Coelho EP. (Ed), II Enc Nac Anilhad Aves. Rio de Janeiro: UFRJ, p. 98-121.

Wunderle JM. 1978. Differential response of territorial Yellowthroats to the songs of neighbors and nonneighbors. Auk 95: 389-395.

ZANN R. 1993. Structure, sequence and evolution of song elements in wild Australian Zebra Finches. Auk 110: 702-715. 